\title{
Remote fatherhood and visiting husbands: seasonal migration and men's position within families
}

\author{
Kamila Fiałkowska(D)
}

Correspondence:

k.fialkowska@uw.edu.pl

Centre of Migration Research, University of Warsaw, Warsaw, Poland

\begin{abstract}
Seasonal migration from Poland to Germany has a long history, yet, there has been a lack of research which would discuss the perpetuating seasonal migration and its entanglements with the family relations. Drawing from the research on seasonal migrants in Germany and in the local community in Poland I look at the situation of male migrants and their family relations in order to add to this research strand. Doing so I built on the context of gender relations in Poland and the still dominant role of men as economic providers and breadwinners. In the economically challenging post-socialist context, fulfilling this societal obligation placed upon them proved to be problematic. Thus migration has become a strategy of social protection, aimed to minimize the social risks to family's wellbeing linked to unemployment and unstable labour market.

Seasonal migration pattern and family relations have mutually constructed each other in a way that, instead of creating transnational familyhood, it may translate into defamilisation: estrangement or marginalisation of the migrants. It thus demonstrates how men's recurring absence affects gender dynamics and their position within families. The way families have adapted to prolonging absence of the migrant and in fact living apart together can be viewed, as I argue, as the noneconomic reasons for the perpetuation of seasonal migration of Polish men to Germany. This paper also addresses modernisation of gender roles and points to the importance of the class dimension. Whilst the discourse on fathering or conjugal relationship usually builds on egalitarian gender roles, this paper, applying the intersectional lenses, brings in the perspective of the working class and rural migrant workers.
\end{abstract}

Keywords: Family, Fatherhood, Gender, Masculinity, Seasonal migration

\section{Introduction}

Seasonal migration of Polish people to Germany has a long tradition. Dating back to the mid-19th century, it stopped due to the WWII and its aftermath - the division of the continent by the Iron Curtain. The turbulent history of Polish-German relations in the 20th century and its significant improvement witnessed the reemergence of seasonal migration patterns. As a result, since the late 1980s seasonal migration again, gradually became one of the numerically most important labour migration flows from Poland to the West (see Kępińska, 2008; Łukowski \& Kaczmarczyk, 2004; Marek, 2008). This irregular

(C) The Author(s). 2019 Open Access This article is distributed under the terms of the Creative Commons Attribution 4.0 International License (http://creativecommons.org/licenses/by/4.0/), which permits unrestricted use, distribution, and reproduction in any medium, provided you give appropriate credit to the original author(s) and the source, provide a link to the Creative Commons license, and indicate if changes were made. 
temporary migration widely contributed to the German informal economy (Cyrus \& Vogel, 2006, p. 75) until it had been regulated by the bilateral agreement signed in December of 1990, a year after democratic transition in Poland and shortly after German reunification. ${ }^{1}$ Migration strategy built around circularity between the two states became one of the few legal options of labour migration available to Polish citizens in the 1990s. and remained among popular economic migration strategies after other European labour markets became legally accessible for Polish citizens. For many seasonal migrants this became a regular economic activity since the late 1980s. with some continuing to migrate seasonally for more than two decades. At the time of Poland's accession to the European Union (2004) nearly 300,000 people were employed as seasonal workers in Germany (Kępińska, 2008, p. 94).

While the economic aspects of seasonal migration and role of migrant networks in its growing popularity has been widely researched in the Polish context (Jaźwińska \& Okólski, 2001; Kępińska, 2008; Korczyńska, 2003; Łukowski \& Kaczmarczyk, 2004), the impact of seasonal migration on families, surprisingly, has not been a subject of an academic inquiry. Seasonal migration makes migrants return to their homes frequently. Ruptures in functioning of the family did not appear to be significant as in other transnational family arrangements when migrant's separation from family is of more permanent nature. Seasonal migration was also not seriously considered in the research on social remittances, the temporality of migration seemed to limit the research scope to the mostly economic aspects and network effects. Similar observation were made by Leah Schmalzbauer about the relative lack of focus in the research and policy discussions on family, gender and fatherhood in particular in the case of guest workers (Schmalzbauer, 2015, p. 212).

Having said that, changes in functioning of the family, relationship with the migrating family members, their positioning and power relations within families including gender relations have been recurring topics in my fieldwork on seasonal migration from Poland to Germany. This fieldwork was conducted among Polish seasonal migrants and lasted over a year in multiple locations in both countries, through 2010 and 2011. During this time I was able to take part in migrants' daily lives, observe and talk to them. Therefore, in this paper, applying the gender lens on seasonal migration, I want to discuss the impact of seasonal migration on families and their functioning in order to see if it contributes to the reasons underpinning perpetuation of seasonal migration from Poland to Germany in new socio-economic circumstances. These new circumstances refer to joining the EU and decreasing economic attractiveness of the seasonal migration for the last two decades.

I will consider the interdependencies between gender and migration, especially how do gender relations change as a result of long engagement into seasonal migration and whether the construction of gender relations in Poland can inform us about the migration practices and decisions. While most of the literature on gender, migration and social protection within transnational families deals with women, there is a growing body of literature which discusses men and migration related issues. This article will contribute to the latter and given the changes in functioning of the family of seasonal migrants it will discuss how masculinity, men's role making and migration patterns intertwine. Analysis from the transnational family and gender perspectives offers a better understanding as to why migrants engage in circular migration over long periods of time, 
how their repetitive migrations have been incorporated into the regular life of the family and what mechanisms supporting it are at play.

As it is argued in the literature, the construction of masculinity puts certain obligations upon men which were difficult to fulfill in the post-socialist context (Dąbrowska, 2011; Mazierska, 2008; Wojnicka \& Ciaputa, 2011). Migration presented itself as an opportunity to minimize social risks associated with unemployment, unstable labour markets and a way to provide social protection to the families. This entailed repetitive and prolonging absences and short returns after work periods abroad which can be viewed through the transnational lenses. These recurring absences require certain arrangements to family functioning which subsequently changes the nature of relations between the partners and children (c.f. Bryceson \& Vuorela, 2002; Hondagneu-Sotelo \& Avila, 1997; Lutz, 2004). The renegotiation of family norms and care obligations are crucial when it comes to doing transnational family and intersect with gender regimes and social mechanisms, which structure formal and informal protection arrangements (Bilecen \& Barglowski, 2015). Migration regime, too, plays a distinctive role here, as it has imposed temporality on migrants life. This, in many cases, have hampered the chances of e.g. upward labour market mobility in the destination country or settlement options for the migrating farm workers, comparing with other, more privileged categories of migrants.

Seasonal migrants from Poland to Germany are mostly working class, by and large migrating farm workers. The post-EU accession emigration from Poland overshadowed seasonal migration by numbers of migrants heading to the UK and Ireland but also by research enthusiasm towards this new phenomenon. As a result, since joining the EU majority of the research on Polish migration have focused on the EU superstars, mobile youth, families and professionals who settled down in the UK or Ireland (cf. Burrell, 2009; Favell, 2008; White, 2011). Whilst the seasonal migration continues to exist, this paper brings in the experience of those migrants, who are not in this focus both in geographical and class terms.

First, I discuss the transnational families and gender roles, giving the overview on migration literature in this area of studies. Then I move on to the issues related to family and migration, rooting it more deeply in the Polish context. The next section is devoted to methodology. Following that I discuss empirical findings. These allow me to conclude on the ongoing negotiations related to gender norms in transnational families and their impact on male positionality within families and migration patterns.

\section{Transnational families and gender roles in flux}

The relations between the migrating and non-migrating members of a family and the way they change due to migration are subject of continuous investigations and research interest amongst migration scholars. Transnational methodological approach helps in considering the simultaneity of the practices and transactions between migrants and those who have not migrated (Amelina \& Faist, 2012) as it provides a better insight into the relations and dynamics between the family members. According to Deborah Bryceson and Ulla Vuorela, transnational family can be understood as a family whose members "live some or most of the time separated from each other but yet create a feeling of collective welfare and unity, namely "familyhood", even across national borders" (Bryceson \& Vuorela, 2002, p. 3). 
However, the popular and long-lasting assumption of "natural" qualities of a family such as love, solidarity, reciprocity, help, respect, etc. (Crow, 2002, p. 52) has been criticized for its simplistic view on familial solidarity. Family members do not always agree upon economic strategies and solidarity and support networks among their members might be strained. Family members might have different agendas, not necessarily holding on to what is believed as to bringing benefits to the family, but instead realizing their own individual ambitions. "The migrant is a gendered subject, embedded in a wide range of social relationships" (Castles \& Miller, 2003, p. 36), and social embeddedness of the actors constituting a family - relations, norms, gender roles, identity and former relations - is an important dimension of the analysis of migratory behaviours which needs to be acknowledged more in the discussions (De Haas, 2010, p. 1607; Faist, 2004, p. 41). More recently, the embeddedness of the migrants have been taken up with authors pointing to the moral regimes of the country of origin regarding negotiations in the realm of social protection (ethnomoralities of care, in: Kordasiewicz, Radziwinowiczówna \& Kloc-Nowak, 2017). Also, since the gender orders differ in sending and receiving countries (cf. Brannen, Mooney, Wigfall, \& Parutis, 2014; Donato, Gabaccia, Holdaway, Manalansan, \& Pessar, 2006) we may observe reproduction, transformations (and modernizations) or resistance to changes of gender roles. These may put not only migrants under strain but also the relations between migrating and non-migrating family members.

The gender order which this paper refers to is the breadwinner and housekeeper model, according to some researchers the still dominant pattern of functioning of many Polish families (Wojnicka \& Ciaputa, 2011). There is a growing diversity in family life reflecting changing gender ideals. However growing variety of masculinity models (e.g. caring masculinity, new (involved) fatherhood Coltrane \& Allan, 1994) and changing notions and ideals of masculinity did not overthrew the masculine ideal which still strongly relates to power, economy, sexuality (heteronormativity) and aggression/defence (Dąbrowska, 2010). This can be also viewed through the lens of hegemonic masculinity, the much discussed concept of Raewyn Connell (Connell, 2005; Connell \& Messerschmidt, 2005; Wojnicka \& Ciaputa, 2011). Hegemonic masculinity, as an ongoing gender project, represents then the currently most valued ideal of a man. Men are compelled to somehow relate to this ideal - i.e. to aspire to, negotiate with or reject it. As a certain gender practice dominance and privileged position of men in a particular society does not require violence, although it can be supported by force, and achieves ascendancy through culture, institutions, and persuasion.

Gender relations in the Polish society and male positionality especially within working class and rural families which were in the scope of my research and their interrelation with migration are insightful for better understanding of the way migration became a routinised practice in the given local community. Therefore, for further argument in the following section I will present a brief overview of migration, families, and gender in the Polish context which I relate to the rural and working class population of seasonal workers where my research was conducted.

\section{Gendered migrations and endangered families}

Polish academia has been a latecomer in applying the gender lens to migration studies. However, with gender becoming an indispensable element of analysis of migratory 
processes, research was largely focused on migration of women (Kindler \& Napierała, 2010; Slany, 2008; Urbańska, 2008, 2015), what reflects similar developments elsewhere in the world, ever since migration studies were criticized for the lack of gender perspective (Hondagneu-Sotelo, 2013, p. 234). Research on masculinity and Polish migrants started emerging from afar, initially by British-based scholars (see e.g. Brannen et al., 2014; Datta, 2008, 2009; Garapich, 2011; Siara, 2009, 2011, 2014). Further studies considered male obligations in transnational families and negotiations of gender order (see e.g. Barglowski, Krzyżowski, \& Świątek, 2015; Kilkey, Plomien, \& Perrons, 2014; Pustułka, Struzik, \& Ślusarczyk, 2015).

This overwhelming focus in migration studies on women, and concerns of care and family well-being in the context of absent mothers is reflected in the language. The wide use of terms such as "crisis of care" (Parreñas, 2005, p. 12), "care chain" (Parreñas, 2001) or "care drain" (Hochschild, 2003, p. 17) usually point to absent mothers, while fathers' absence, has been widely accepted and normalized (Parreñas, 2008). This literature acknowledges the popular perception of roles men and women play in the society - mother's figure is often presented as a guardian of a family nest and her absence is considered to be more damaging to the functioning of the family. The research among migrants from rural and working class populations in Mexico and Poland confirms that the popular view on gender role divisions is that of fathers supposed difficulties to take up the women's role in the family and the household as it requires more effort and adjustment (Aguilera-Guzmán, de Snyder, Romero, \& Medina-Mora, 2004; Kępińska, 2013).

This corresponds with the still present and widely exploited in popular culture, yet also contested, model of female identity in Poland, which is loaded with national and religious meanings (Dąbrowska, 2011). The cult of virgin Mary, with Marian devotion being central to Catholic spiritualism in Poland allowed for conceptualisation of the feminine within the nation, flexible enough to contain the powerful, resilient Mother Pole figure - "Matka Polka", who gave birth to the sons of the nation, to fight for the fatherland but also an exemplar for feminine domesticity. As put by Awsiukiewicz-Tomczak (2009, p. 142) "women were expected to conform to ideal allegories by being noble, brave, and strong but also humble, devoted, and at times tormented, to reflect the condition of the state and the nation". Increasing number of migrating women, "the managers of family life" (Titkow, Duch-Krzystoszek, \& Budrowska, 2004, p. 65), in the 1990s as well as during the years following the EU accession of Poland caused "moral panic" and discussions on families in crisis due to migration. Supposed "crisis of care" eventually coined the euro-orphanhood term which on the one hand points to the "left behind" children, but on the other, largely blame the transnational mothers for such situation (Lutz, 2010; Urbańska, 2008, 2015). Yet, the migrating fathers were respected for their sacrifice for the well being of families (Avila, 2008). Men, absent from the family life, were missing in the discussions about migration's impact on parenting too (Kilkey et al., 2014).

Research on masculinities in Central and Eastern Europe, although still underdeveloped (Wojnicka \& Ciaputa, 2011), emphasize the heritage of communism, democratization and introduction of capitalism and free market economy which accounts for the specificity of the post socialist context. While socialist state put women 
at work and maintained their role as a mother, men on the other hand were still purely economic providers. The gender relations under socialism, as some authors claim, were not genuinely transformed as to ensure the full emancipation of both men and women (Fidelis, 2004, 2010). As such, socialist state did not transform power dynamics within families but rather sustained traditional views on masculinity, hence reinforced traditional gender roles in the society (Novikowa, 2012, p. 97). The transformation of 1989 and changing socio-economic realities offer distinct conditions for reshaping of the male identities.

According to Bator (1999) there were two prevalent discourses that shaped the gender views in Poland in the 1990s; a nationalist, conservative and patriarchal discourse based on the ideology of Roman Catholic Church and a liberal discourse treating women as equal citizens aware of their rights and who should fully participate in public life. However, as some notes, the rise of masculinism was the primary characteristic of gender relations after transformation in Poland (Watson, 1993). Social policies essentialized gender differences whilst men were promoted in the public spaces, and women excluded through discourse of roles that women and men should play in the society. The nation was a main point of reference of public discourse, in which women's role was reinforced as traditional guardians of family nest and men's role in public space, taking care of the wellbeing of family, and wider - of a nation (Titkow, 1993; Titkow et al., 2004). These processes were occurring in the context of downsizing of the welfare state and uncertain future in rapidly changing labour market thus it had reinforced men's traditional roles as head of the households, protectors of families from the outside unpredictable world. This retraditionalization in Polish context is also ascribed to the power of Roman Catholic Church, as well as negation of achievements of the communist state. The conservative interventions of the church, related to e.g. religious education in public schools whilst effectively keeping sex education out of it or access to abortion were synchronised with the wave of negation of the state-socialism heritage and return to the traditional views of what is "normal" (especially in gender terms). This, as Watson claims, was a vehicle of change, namely retraditionalisation, in the Central and Eastern Europe (1993) From this standpoint comes critique of working mothers, as supposedly neglecting their natural instinct or discussions on limiting the, liberal during the communist regime, access to abortion, which continues to this day. Thus, it is identified that masculinity, defined by work outside of a household, traditional marriage and reproductive capacities as spaces of self-validation as a men, was supported by the patriarchal social system (Dąbrowska, 2011, p. 242; Marody \& Giza-Poleszczuk, 2004).

However, due to the economic crisis and increasing unemployment rate men could not fulfill the traditional roles of breadwinners, thus the post-socialist transformation led many to think about this time as worst in their lives (Mazierska, 2008). These negative changes affected largely the rural populations which are the focus of my research (Jaźwińska \& Okólski, 2001). Subsequent emigration to the West, which exacerbated after the country's accession to the EU, can be therefore viewed as livelihood strategy, but also a strategy of re-assuming the role of a men within family and fulfill societal expectations placed upon them, according to hegemonic masculine ideal. 


\section{Methodology}

I conducted a multi-sited ethnographic research among the Polish seasonal migrants in few localities in sending and receiving communities (i.e. local community of seasonal workers origin and place of work respectively). In line with the transnational methodology this allowed for combination of both socio-spatial perspectives (Barglowski, Bilecen, \& Amelina, 2015). Long-lasting field research and multi-local data collection included methods of overt and covert participant observation, semi-structured interviews, photo-ethnography, and focus groups (reference anonymised for peer review). This research design allowed for following the migrants and meeting them in various locations in the community of origin, as well as in Germany, at their workplace, often meeting their families and friends, visiting their houses on various occasions, attending family ceremonies or being invited to casual gatherings during weekends - all these allows for acknowledging "a dialectical relationship between mobility and immobility" (Amelina \& Faist, 2012). For the need of this paper I focus on the local community in Poland, and my argument is based on the data collected there - both interviews with the migrants, their relatives, friends and spouses as well as the observations which I was able to conduct due to long time spent on the field site. I was able to get to know some of my research partners as well as their millieu and built rapport which lasted much longer than brief encounter to conduct an interview. Thus, in order to protect the anonymity of my research partners I use the pseudonyms wherever I refer to their accounts on particular matters.

I was interested in the beginnings of the seasonal work abroad, experience of working abroad, development of migration networks, which allows for expansion of seasonal migration in the local community and functioning of families who implemented seasonal migration into their livelihood. The empirical field was located in the voivodship which recorded the most significant growth in number or seasonal workers between the 1992 and 2002 (Kępińska, 2008). The research site was a local community of the town of less than 30 thousand inhabitants and neighbouring villages.

During the fieldwork phase in Poland I have conducted interviews with 40 seasonal workers (some of them have also had other migratory experiences to another countries) and I was also able to conduct participant observation by living in this town for nearly 8 months. All the interviewees were reached using snowballing method - initially with the help of representatives of local government, cultural institutions, NGOs and local entrepreneurs, and finally - migrants themselves. The age of interviewees differed a lot, from those who, at the time of fieldwork were nearing 60 years of age to those migrants who were only in their twenties. Male and female interviewees over 50 years of age have had particularly difficult situation on the local labour market.

With the political and economic transformation in the 1990s the region of my fieldwork had experienced significant economic troubles when the major state-owned company started reducing employment and eventually went bankrupt. This in turn affected other smaller contractors, who had to close down their business or reduce employment. Agriculture has never been the major activity for the people living in the neighboring villages, there was no major industry and the town is surrounded by large areas of forests. That is why, either during an interviewing or having informal conversations, interviewees or locals often mentioned that people had to be 
resourceful to survive. Temporary migration had quickly become one of the key livelihood strategies employed by many, while the local labour market became unable to accommodate all the workers.

My research partners who entered the labour market in 1980 and 1990. worked in local state owned companies. When these enterprises went bankrupt they had to retrain in order to be able to find employment elsewhere. Oftentimes, even retrained, they eventually get registered as unemployed, or working in the shadow economy (or both). Since the end of the 1980s, informal employment or petty trade in Germany has been quite common for Polish men and women alike (Morokvasic, 2004; Stola, 2010). In my sample, men dominated in the pioneers' excursions taking place as early as in the 1980s. As such these often short trips across the border in search for work were perceived as risky, hence female migrants were in minority.

Some of my younger interviewees hold university diploma (Bachelors or MA), often obtained at regional private institutions of higher education or in nearby universities in the city of Lublin which often were useless on the local labour market. Not quite ready for permanent settlement elsewhere, seasonal migration was and still is a way to stay put and have regular inflow of money.

I was able to meet and talk both formally and informally with migrating and non-migrating spouses, children of the migrants, some of whom were also circulating between Poland and Germany, friends and relatives of the seasonal migrants. Having met the pioneers of seasonal migration and other long term seasonal migrants in this local community helped me in understanding the actual impact of this migration on their personal life and on life of their families. As a result, this allowed me to deconstruct some common notions about the functioning of migratory households and migration networks. My own experience as a seasonal worker was coming in handy, as it helped to position myself not only as an interested, but not very well experienced $\mathrm{PhD}$ student, but also as a person who can personally relate to the joys and struggles of a seasonal workers. Contacts, discussions, and observation of relations within families with long experience of seasonal migration and enduring absence of some of its members contributed widely to my perception of a transnational family.

(un)becoming a nominal father

For most of my male interviewees, migration to Germany started as an economic necessity following the bad economic situation on the local labour market. Hence it allowed them to fill in the role of a breadwinner, the one who supports family financially while also filling in the script of a successful migrant - who is able to find a job and send money back home to support their families. From this standpoint, migration to Germany can be perceived as crucial not only in terms of economic benefits but also pinpointing to the understandings of masculinity. As Dreby noted (2006), remitting fathers are often excused from providing emotional care, which is quite opposite for migrating mothers - women's role within family if associated with emotional care provisions thus their absence is more difficult to justify. Providing financially migrating fathers may slowly disengage from family life and become a "nominal father" (Castaneda \& Buck, 2011), or "father by the cheque" (Hondagneu-Sotelo, 1994, p. 67). In other words, it describes how turning to financial provisions becomes a primary way of 
fatherly involvement in the wellbeing of families which substitutes for lesser involvement with hands-on care (for similar discussion about care provisions between migrants and their elderly parents see e.g. Barglowski, Krzyżowski, \& Świątek, 2015).

Process of becoming a nominal father is inscribed in one of my interviewee's experience. Agnieszka grew up not seeing her father too often, as he spent most of the year in Germany working in a farm. Her father's rare visits at home evolved from being awaited to disturbing the regular family life:

I was annoyed when he was at home for too long, but you know it is not like that...I missed him a lot, when I was younger, but then I got used to it that I talk to him over the phone (...), but then I didn't talk to him about my important things, he was away and when he was back he tried to, you know, to organize everything, as if he never left, like...to be at home on this hour, don't bring your friends over, these things, and when I grew older we argued a lot when he was at home, I was so looking forward for him to go to Germany again. (Agnieszka, 30)

She stressed the temporal aspect of migration - it was not one off - Agnieszka's father was regularly working in Germany, spending there most of the time per year, during which she grew from a little girl to the age of adolescence. Maintaining emotional connection between a father and a daughter was challenging and regular returns and absences proved disruptive to their relationship. The distance between the two grew with passing time. Her late childhood and growing up period happened without having him around. As she recalls, her father tried to reassume his pivotal role in a family when at home, which caused tensions (cf. De Haas \& Fokkema, 2013, p. 222). Therefore, as Agnieszka expressed, she was at ease when her father was abroad.

Conforming to the traditional scripts of gender labour division within the households migrant fathers more easily free themselves from emotional labour and relegate all the emotional and caring work on their spouse (Parreñas, 2008, p. 1067). While this can be the case here, the importance of power imbalances within the families and migrant embeddedness should not be overlooked. Agnieszka's father could exercise his role as a father mostly as an economic provider due to his prolonging and repeating absences. Financial remittances are important, but their influence on family relations goes far beyond the economy and financial situation of a family - they affect relations within a family, social and gender roles contributing to the emotional gap between migrating and non-migrating family members (cf. Parreñas, 2008). As a form of reciprocity for financial care he may have expected respect and love. These altogether would maintain his status in the family, however, his daughter did not perceive him as emotionally supportive figure. Quite opposite, she found it difficult to reconcile love and respect with absence and withdrawal of her father from everyday matters.

Discussed case shows how migration and fathering reciprocally affects one another migrating fathers experiencing emotional estrangement from their children hold on to financial means as a way to substitute for their lack of other involvement into family matters. With migration becoming a long term strategy in order to provide to the family on the desirable economic level they fulfill their duties towards their children. 
Attempts to reaffirm their role as a disciplining and authoritarian figure can be viewed as a strategy to maintain the unchallenged position within the household.

Tadeusz spent more than two decades of his life working seasonally in Germany, starting in 1988 together with his wife. While both Tadeusz and his wife were working in Germany, their child was cared for by the grandparents. They divorced in early nineties and Tadeusz has had rare contacts with his son:

You know, children are little lost, even if they stay with grandparents, I think both parents should be there for them, to bring them up and to care for them. They can be little lost, like my Maciek [Tadeusz's son] is now, but, you know, I have never truly been with him. (Tadeusz, 47)

As Tadeusz claims, his work and absence at home was primarily a result of economic needs of a young couple, who had been living with their in-laws and dreaming of their own place to start a family together. The earnings in Germany made him reluctant to ever get back to work in, then socialist, Poland. Later on, during the transformation of 1989 and in the following years, seeing how his own parents are struggling financially, he had decided that it was his duty to provide for them. Meanwhile, his son was born and the economic needs of the family increased. The pressure put on Tadeusz turned his migration from few episodes into a routine - few months in Germany, few weeks at home schedule have lasted more than two decades. Tadeusz does not blame divorce nor the mother for the emotional distance that he now has with his grown up son, as it has been reported in some other research (see e.g. Kilkey et al., 2014, p. 184). Instead he agrees that his lack of emotional rapport with his son was his failure to engage more in fathering. Reflecting upon his experience he claimed that his ambition was that his family would never suffer poverty. While the local opportunities were scarce he found a way to satisfy these needs abroad, however, he has become a nominal father in the course of time and estranged himself from his son and wife.

Another interviewee, Mateusz, father of a toddler, expresses the desire of working permanently in Poland and being with a family, something that Tadeusz regrets he did not manage to successfully implement:

\section{K: So when are you leaving?}

Mateusz: I go today, at night.

\section{K: So does your son know that you go tonight?}

M: No, this would be too hard. He goes to sleep and then I go (...) Just few years more, when he is older I want to be more at home than there (...) (Mateusz, 34).

Mateusz wants to be more active and involved father. His plan is to invest money into a business in Poland and stop migrating. This, he hopes, will allow him to spend more time with his family, especially when his son will grow older. As he puts it later on during the interview he does not want to be the father with whom his son does not have anything in common, and this, as he perceives inevitably would be a consequence of extending the regular circulatory migration. This also shows that migrants fear that 
extended periods of absence at home and limited involvement into family affairs may result in the marginalization within the family. Mateusz wants to play an active role in his son's upbringing, and the prospect of supplying money, but not spending time, hence eventually becoming a "father by a cheque" does not appeal to him.

The temporal aspect of seasonal migration applies also here - prolonging and repeating absences are inevitably accompanied by other processes within families, namely growing up of the interviewees' children. Growing awareness and pressure on active and engaged fatherhood, which modernize the hegemonic masculine ideal put male migrants under strain (Pustułka et al., 2015). While providing economically, emotional provisions require more effort. Some migrants therefore attempt to compensate for their absence by sending gifts or doing leisure activities that entail reciprocal obligations, or at least respect and obedience to the father as demonstrated in the case of Agnieszka.

Men fulfilling their economic obligations towards their family are also faced with family expectations towards the achieved or expected standard of living or amount of remittances. Migration therefore becomes a strategy to provide for their families on a desired level. Uneven economic development in Poland, which was observed during the last two decades, proved that local labour markets, especially in less economically developed regions (one of which is where the fieldwork was conducted) in most cases could not satisfy these expectations (Grabowska-Lusińska \& Okólski, 2009), hence making seasonal migration most likely to continue. These aspects as discussed here show that fathers' agency and local economic structure combined may have an impact on whether migration will or will not turn into routinised activity.

\section{Becoming a nominal husband}

The enduring absence of men in this context has also impact on conjugal relations, which may influence the subsequent migration decisions and consolidation of such status quo. Anna, who is a 54 year-old nurse and whose husband regularly since two decades spent part of the year working in Germany, says I have everything organized, what to do, where to go shop, I then sit with my friends over a coffee, that's how it's going, (...) sometimes I wait for him to go.

It appears that her husband disrupt her daily routine when he is at home. Meanwhile, when I had a chance to talk to her husband about how their relationship had changed over time, he also complained that his wife is constantly unsatisfied with him: ah, this is always like that, either the money are too little, or I put something in a wrong place (...) women are like that, when I am there at least nobody yells (...) but I always give her all of the money (Henryk, 56).

Analyzing his situation, Henryk refers to the traditional gender scripts - men provides economically and women takes care of the house and family. He considers it unjust that for his sacrifice - working abroad and bringing money home, in bigger amounts than he would have earned back home - he is treated like an intruder, as he feels. It seems that the couple have unlearned to live with one another. Perpetual absence and short, intermittent stays at home of Henryk allows Anna to organize her life according to her needs and likes. Often the time spent together is rather stressful and filled with mutual misunderstandings, especially when Henryk's stays at home were 
extended due to, e.g. failure to secure employment for the next season. Absence from daily family life has become a relief from the family related stressors. As a result, though, he has become a marginalized figure in the household, which has also affected relations with his children - two grown up sons and one daughter, who seems to treat him with reservations, as causing problems when at home. As noted by other researchers, in the situation of spatial distance it is good relations with a mother which helps in maintaining good understanding with the children (see e.g. Schmalzbauer, 2015). Hence tension between the couple may negatively affect relations with children. Henryk sees that when he is "there" he "rests" from family problems, similarly for Anna who stays "here" while he is away. As a result he have felt pushed by his family and above all - by himself into the role of an absent husband and a father (cf. Palenga-Möllenbeck, 2016, p. 234).

Seasonal migration as a rest from family affairs and mundane every day after-work duties is noticed by several interviewees as well as my coworkers during the time of my fieldwork. Justyna (31) in our conversation reflects on it:

In a long run it is really convenient. Nobody talks about it that way but I really rested there, I was at work but simultaneously it felt like holiday! If I wouldn't have a child I would be eagerly waiting now for the new season, I really regretted declining the offer when I found that I'm pregnant.

Justyna here brings back the gender dimension, she now remains at home with her yet little children, and precisely for that reason she is not longer able to work seasonally in Germany. This, as she recalls allowed her some time off her everyday life, something that is more easily accepted in the case of migrating fathers. As such it has been observed that fathers, unlike mothers, will be more easily excused when not being fully successful in the modernised role of a father (Pustułka et al., 2015). However, as I observed during my fieldwork, there has been a growing criticism towards perpetuating and repeating absence of a father and a husband and impact it has on the family. Similar account comes from Mateusz (34) who as mentioned before, does not want to become a nominal father to his son. Possibly also because he is witnessing the process of becoming both, nominal father and a husband on the example of his brother: I know that she misses the everyday life with him but I also see that my brother got used to this freedom, wife and children on everyday basis are tiring.

Economic migration has been perceived as a disengagement from family, which clashes with the new fatherhood ideals. Magda, who herself had experience of migrating to Germany which she stopped doing after getting married and having a child, refers to the situation of her close friend, whose husband is regularly away to work in Germany:

My friend's husband works abroad for five years now. They bought a flat and he now works and sends the money. He comes home every few months for two weeks or so, so when he comes she walks so tensed and nervous, he disturbs her when he's at home. Usually they are happy for couple of days, then there is a huge fight and then he leaves (Magda, 33) 
Being nervous and tensed can be accredited to a fact that learning to live together is a skill that needs practice and physical presence. Therefore episodes of husband's home visits are not regarded as regular life together, but something that disrupts the routine, which came clear in the relation of Anna and Henryk. Justyna (31) in our conversation, somewhat critically, refers to the fact that all the effort of everyday work and raising children is on the mother's side, who cannot afford to leave temporarily, while fathers enjoy the rituals of short family visits and bonding with the children in a more playful way: I even think for him it is more convenient, he comes home and he is like a Santa, coming with the gifts. The argument which adds to the discussion that perhaps norms of a "proper" hands-on and loving parenting are more lenient for men than the strict and unattainable standards for women' (Pustułka et al., 2015, p. 122).

My research participants were critical of the "good provider" as it was discussed in the previous sections and see the re-assumption of migrant position within family, upon his cyclical return, as disruptive and stressful. In their views, husband and a father, although making significant sacrifices and not spending enough time with a family, by providing them financially fills out most of their duties as a fathers and a providers and relies completely on the wife for caring for family (cf. Parreñas, 2008). Yet, they can enjoy the relative freedom, which is not available to their at-home-wifes. What is more, the interviewees assume that it is easier to live that way, not to be burdened with family matters on every day basis (Hochschild, 1997). This reflection of her corresponds with findings of Kilkey et al. (2014, p. 184) - doing a family and playing a bridging role between the children and their migrating fathers adds to the workload of mothers, which has been largely unacknowledged by the migrant fathers in their research. It were the mothers, however, who were blamed by them for the emotional loss.

Undoubtedly it would have been more problematic to provide a decent standard of living for the whole family on the local labour market. Hence migration is seen as a way to achieve the first and foremost needs of the household. The absence of the father and a husband is compensated by the gifts and celebratory character of the father's visits. The attempt of all family to enjoy the moments of togetherness can be interpreted as celebrating the way normal family should live their life - when both parents are at home (Urbańska, 2015). However, this socially accepted normality is stressful and demanding. The new normal for the life of that family is to be apart.

Migration had changed the way family functions, in a way that living together apart is the way all family members feel most comfortable (cf. Beck \& Beck-Gernsheim, 2013). This way long lasting, perpetuating absence of the father and transnational family life have reconfigured family relations.

\section{Conclusions}

Family life and love without everyday presence becomes a reality for a growing number of people living on the peripheries of global capitalism (Beck \& Beck-Gernsheim, 2013) and physical presence has became a sign of welfare and a marker of economic and social inequalities in local and global dimension (Palenga-Möllenbeck, 2016). Migration regimes force certain categories of migrants to regularly circulate between place of work and home, where they spend time in between employment in another country. Meanwhile, their families become dependent on the remittances, thus adding to 
pressure on migrants not to stop circulating. It bears certain consequences, including risk of marginalization both in the country of destination and in local communities.

According to de Haas and Fokkema (2013, p. 225), those who choose pendulum migration as opposed to definite return or settlement in the country of emigration may have done it due to different imbalances within the households. Indeed, the presented cases of men's long-lasting involvement in seasonal migration and building transnational families, have shown potential for transnational migration to translate into defamilization (Lister, 2012) rather than into a specific transnational familyhood. Adaptive behaviours of remaining family members may be disruptive for the family functioning, especially when migrant returns and attempt to re-assume the role he used to play before migrating (Schmalzbauer, 2004). Simultaneously, relationship between partners is often under a lot of strain, when migration translates into physical as well as emotional distance.

Seasonal migration temporarily frees the migrants (and non-migrants) from aroused family problems which also contributes to emotional absence, and consequently may lead to defamilisation. Unlike for mothers it is easier for men to justify their absence, as long as they are capable to fulfill the ascribed by the society role of masculine ideal, a "good provider" (see e.g. Parreñas, 2008; Pustułka et al., 2015). However, this does not remain without consequences for the spouses and the children. Thus more attention should be placed on the remaining family members, as the research shows that the gender ideals and the perpetuating migration of a father does influence one another. Moreover, this would allow for better understanding of the marital and parenthood dynamics, potentially also consequences for the family future (i.e. care arrangement and care expectations, aging, etc.).

Finally, as Schmalzbauer (2015, p. 212) notes discussing the long lasting involvement of migrants into guest worker program, family and fatherhood were the primary reasons for men to enter and to remain in this form of mobility. This was also the case for most of my male interviewees. The functioning of migrants between "here" and "there", attempts to meet the expectations placed upon them from traditional perception of gender roles but also to meet the, strongly related to money and economic potency, masculine ideal may contribute to long lasting involvement and routinisation of chosen migration strategy. Yet, the maintenance of traditional gender roles for migrant men willing to fulfill their roles of breadwinners via migration and providing social protection to their families - bear risks of their marginalization within the families and finding their position as head of the households contested by the changing power dynamics between family members.

\section{Endnotes}

${ }^{1}$ Migrants were initially allowed 3 months of work, then 4 months in 2004 and finally 6 months in 2009. Sectors of their employment were limited to what was understood as a seasonal work. As a result most migrants were employed in agriculture, horticulture, gardening, construction industry (only until 1993). 
Funding

N/A.

\section{Availability of data and materials}

Data sharing not applicable to this article as no datasets were generated or analysed during the current study.

\section{Authors' contributions}

The author read and approved the final manuscript.

\section{Authors' information}

Kamila Fiałkowska, PhD, is a researcher at the Centre of Migration Research, University of Warsaw. Her research interests focus on various issues related to post-accession migration of Poles and feminist theory, gender studies and social inequalities.

\section{Competing interests}

The author declares that she has no competing interests.

\section{Publisher's Note}

Springer Nature remains neutral with regard to jurisdictional claims in published maps and institutional affiliations.

\section{Received: 24 April 2018 Accepted: 14 December 2018}

Published online: 30 January 2019

\section{References}

Aguilera-Guzmán, R. M., de Snyder, V. N. S., Romero, M., \& Medina-Mora, M. E. (2004). Paternal absence and international migration: Stressors and compensators associated with the mental health of Mexican teenagers of rural origin. Adolescence, 39(156), 711.

Amelina, A., \& Faist, T. (2012). De-naturalizing the national in research methodologies: Key concepts of transnational studies in migration. Ethnic and Racial Studies, 35(10), 1707-1724.

Avila, E. M. (2008). Transnational motherhood and fatherhood: Gendered challenges and coping. Los Angeles: University of Southern California.

Awsiukiewicz-Tomczak, A. M. (2009). Gendered Symbols and Identities in Post-Communist Poland. In C. Beckett, O. Heathcote, \& M. Macey (Eds.), Negotiating Boundaries? Identities, Sexualities, Diversities: Cambridge Scholars Publishing.

Barglowski, K., Bilecen, B., \& Amelina, A. (2015). Approaching transnational social protection: Methodological challenges and empirical applications. Population, Space and Place, 21(3), 215-226.

Barglowski, K., Krzyżowski, Ł., \& Świątek, P. (2015). Caregiving in polish-German transnational social space: Circulating narratives and intersecting heterogeneities. Population, Space and Place, 21(3), 257-269.

Bator, J. (1999). Wizerunek kobiety w polskiej debacie politycznej: perspektywa feministyczna [The owman's image in the polish public debate: a feminist perspective]. Warszawa: Instytut Spraw Publicznych.

Beck, U., \& Beck-Gernsheim, E. (2013). Miłość na odległość. Formy życia w epoce globalnej [Distant love]. Warszawa: Wydawnictwo Naukowe PWN.

Bilecen, B., \& Barglowski, K. (2015). On the assemblages of informal and formal transnational social protection. Population, Space and Place, 21(3), 203-214.

Brannen, J., Mooney, A., Wigfall, V., \& Parutis, V. (2014). Fatherhood and transmission in the context of migration: An Irish and a polish case. International Migration, 52(1), 165-177.

Bryceson, D., \& Vuorela, U. (2002). The transnational family: New European frontiers and global networks. Oxford: Berg Publishers.

Burrell, K. (2009). Polish Migration to the UK in the 'new' European Union: After 2004. Ashgate publishing.

Castaneda, E., \& Buck, L. (2011). Remittances, transnational parenting, and the children left behind: Economic and psychological implications. The Latin Americanist, 55(4), 85-110.

Castles, S., \& Miller, M. J. (2003). The age of migration: International population movements in the modern world. New York: Palgrave Macmillan.

Coltrane, S., \& Allan, K. (1994). New fathers and old stereotypes: Representations of masculinity in 1980s television advertising. Masculinities, 2(4), 43-66.

Connell, R. (2005). Masculinities, (2nd ed.). Cambridge: Polity Press.

Connell, R. W., \& Messerschmidt, J. W. (2005). Hegemonic masculinity rethinking the concept. Gender \& Society, 19(6), 829-859.

Crow, G. (2002). Social solidarities: Theories, identities and social change. London: Open University Press,

Cyrus, N., \& Vogel, D. (2006). Managing Access to the German Labour Market: How Polish (Im)migrants Relate to German Opportunities and Restrictions. In F. Düvell (Ed.), Illegal Immigration in Europe: Beyond Control? (pp. 75-105). London: Palgrave Macmillan UK.

Dąbrowska, M. (2010). Męskość w okresie transformacji: zmiana ekonomiczno-społeczna a polityka płci na przykładzie debat aborcyjnych w Polsce [Masculinity at the time of tranformation: socio-political change and politics of gender on the example of the abortion debates in Poland]. In M. Dąbrowska, \& A. Radomski (Eds.), Męskość jako kategoria kulturowa [Masculinity as a cultural category]. Lublin: Praktyki męskości.

Dąbrowska, M. (2011). Męskość, aborcja i ekonomiczne przemiany okresu transformacji [Masculinity, abortion and economic change at the time of transformation]. In K. Wojnicka, \& E. Ciaputa (Eds.), Karuzela z mężczyznami. Problematyka męskości w polskich badaniach społecznych [Carousel with men. Masculinities' issues in Polish social research]. Kraków: Oficyna Wydawnicza Impuls

Datta, A. (2008). Building differences: Material geographies of home (s) among polish builders in London. Transactions of the Institute of British Geographers, 33(4), 518-531. 
Datta, A. (2009). Places of everyday cosmopolitanisms: East European construction workers in London. Environment and Planning A, 41(2), 353-370.

De Haas, H. (2010). The internal dynamics of migration processes: A theoretical inquiry. Journal of Ethnic and Migration Studies, 36(10), 1587-1617.

De Haas, H., \& Fokkema, T. (2013). Transnational return and pendulum migration strategies of Moroccan migrants: Intrahousehold tensions and conflicts of interest. In L. Oso, \& N. Ribas-Mateos (Eds.), The International Handbook on Gender, Migration and Transnationalism. Edward Elgar Publishing.

Donato, K. M., Gabaccia, D., Holdaway, J., Manalansan, M., \& Pessar, P. R. (2006). A glass half full? Gender in migration studies1. International Migration Review, 40(1), 3-26.

Dreby, J. (2006). Honor and virtue Mexican parenting in the transnational context. Gender \& Society, 20(1), 32-59.

Faist, T. (2004). The volume and dynamics of international migration and transnational social spaces. Oxford University Press.

Favell, A. (2008). Eurostar and Eurocities: Free Moving Urban Professionals in an Integrating Europe. Londres, Blackwell.

Fidelis, M. (2004). Equality through protection: The politics of Women's employment in postwar Poland, 1945-1956. Slavic Review, 63(2), 301-324.

Fidelis, M. (2010). Women, communism, and industrialization in postwar Poland. Cambridge University Press.

Garapich, M. (2011). "It's a jungle out there. You need to stick together": Anti-institutionalism, alcohol and performed masculinities among polish homeless men in London. Liminalities: A Journal of Performance Studies, 7(3), 1-23.

Grabowska-Lusińska, I., \& Okólski, M. (2009). Emigracja ostatnia? [An ultimate emigration?] Wydawnictwo Naukowe Scholar. Hochschild, A. (1997). The time bind. WorkingUSA, 1(2), 21-29.

Hochschild, A. R. (2003). Love and gold. In B. Ehrenreich, \& A. R. Hochschild (Eds.), Global Woman, (pp. 15-31). New York: Henry Holt and Company.

Hondagneu-Sotelo, P. (1994). Gendered transitions: Mexican experiences of immigration. University of California press.

Hondagneu-Sotelo, P. (2013). New directions in gender and immigration research. In L. Oso, \& N. Ribas-Mateos (Eds.), The International Handbook on Gender, Migration and Transnationalism. Global and Development Perspectives, (pp. 233-245). Edward Elgar Publishing.

Hondagneu-Sotelo, P., \& Avila, E. (1997). "I'm Here, but I'm there" the Meanings of Latina Transnational Motherhood. Gender \& Society, 11(5), 548-571

Jaźwińska, E., \& Okólski, M. (Eds.) (2001). Ludzie na huśtawce: migracje między peryferiami Polski i Zachodu [People on the swing. Migrations from Polish peripheries to the peripheries of the West]. Warszawa: Wydawnictwo Naukowe Scholar.

Kępińska, E. (2008). Migracje sezonowe z Polski do Niemiec: mechanizmy rekrutacji, rola rodziny i zróżnicowanie według płci [Seasonal migration from Poland to Germany: recruitment mechanisms, role of family and gender differentiation]. Warszawa: Wydawnictwa Uniwersytetu Warszawskiego.

Kępińska, E. (2013). Gender differentiation in seasonal migration: The case of Poland. Journal of Ethnic and Migration Studies, 39(4), 535-555.

Kilkey, M., Plomien, A., \& Perrons, D. (2014). Migrant men's fathering narratives, practices and projects in national and transnational spaces: Recent polish male migrants to London. International Migration, 52(1), 178-191.

Kindler, M., \& Napierała, J. (Eds.) (2010). Migracje kobiet: przypadek Polski Women's migration: the case of Poland]. Warszawa: Wydawnictwo Naukowe Scholar.

Korczyńska, J. (2003). Sezonowe wyjazdy zarobkowe Polaków do Niemiec [Polish seasonal migration to Germany]. Scholar.

Kordasiewicz, A., Radziwinowiczówna, A., Kloc-Nowak, W. (2017) Ethnomoralities of care in transnational families: care intentions as a missing link between norms and arrangements. Journal of Family Studies 24(1), p. 76-93.

Lister, R. (2012). Citizenship and gender. In E. Amenta, K. Nash, \& A. Scot (Eds.), The Wiley-Blackwell Companion to Political Sociology, (pp. 372-382)

Łukowski, W., \& Kaczmarczyk, P. (Eds.) (2004). Polscy pracownicy na rynku pracy Unii Europejskiej na przełomie wieków [Polish workers in EU labour markets]. Warszawa: Instytut Studiów Społecznych Uniwersytetu Warszawskiego.

Lutz, H. (2004). Life in the twilight zone: Migration, transnationality and gender in the private household. Journal of Contemporary European Studies, 12(1), 47-55.

Lutz, H. (2010). Gender in the migratory process. Journal of Ethnic and Migration Studies, 36(10), 1647-1663.

Marek, E. (2008). Praca Polaków w Niemczech: póttora wieku emigracji zarobkowej [Polish workers in Germany: one and a half cenutry of economic migration. Instytut Pracy i Spraw Socjalnych.

Marody, M., \& Giza-Poleszczuk, A. (2004). Przemiany więzi społecznych: zarys teorii zmiany społecznej[Transformations of the social ties: an outline of the theory of social change]. Warszawa: Wydawnictwo Naukowe Scholar.

Mazierska, E. (2008). Masculinities in Polish, Czech and Slovak Cinema: Black Peters and Men of Marble. Berghahn Books.

Morokvasic, M. (2004). 'Settled in mobility': Engendering post-wall migration in Europe. Feminist Review, 77(1), 7-25.

Novikowa, I. (2012). Fatherhood and masculinity in postsocialist contexts - lost in translations? In M. Oechsle, U. Müller, \& S. Hess (Eds.), Fatherhood in Late Modernity: Cultural Images, Social Practices, Structural Frames. Opladen: Verlag Barbara Budrich.

Palenga-Möllenbeck, E. (2016). Unequal fatherhoods: Citizenship, gender, and masculinities in outsourced 'Male'Domestic work. In B. Gullikstad, G. K. Kristensen, \& P. Ringrose (Eds.), Paid migrant domestic labour in a changing Europe. Questions of gender equality and citizenship, (pp. 217-243). UK: Palgrave Macmillan.

Parreñas, R. S. (2001). Servants of globalization: Women, migration and domestic work. Stanford University Press.

Parreñas, R. S. (2005). Children of global migration: Transnational families and gendered woes. Stanford University Press.

Parreñas, R. S. (2008). Transnational fathering: Gendered conflicts, distant disciplining and emotional gaps. Journal of Ethnic and Migration Studies, 34(7), 1057-1072.

Pustułka, P., Struzik, J., \& Ślusarczyk, M. (2015). Caught between breadwinning and emotional provisions: The case of polish migrant fathers in Norway. Studia Humanistyczne AGH, 14(2), 117-140.

Schmalzbauer, L. (2004). Searching for wages and mothering from afar: The case of Honduran transnational families. Journal of Marriage and Family, 66(5), 1317-1331.

Schmalzbauer, L. (2015). Temporary and transnational: Gender and emotion in the lives of Mexican guest worker fathers. Ethnic and Racial Studies, 38(2), 211-226.

Siara, B. (2009). UK Poles and the negotiation of gender and ethnic identity in cyberspace. In K. Burrell (Ed.), Polish migration to the UK in the "new" European Union. After 2004. Aldershot: Ashgate. 
Siara, B. (2011). Construction around body within recent polish migration to the United Kingdom. Studia Migracyjne-Przeglad Polonijny, 37(1 (139)), 111-128.

Siara, B. (2014). Body as gendered and sexualised and recent migration of poles to the United Kingdom. In G. Tsolidis (Ed.), Migration, Diaspora and Identity. Cross-National Experiences, (pp. 157-171). Dordrecht, Heidelberg, New York, London: Springer.

Slany, K. (Ed.) (2008). Migracje kobiet: perspektywa wielowymiarowa [Women's migration. An multidimensional perspective]. Kraków: Wydawnictwo Uniwersytetu Jagiellońskiego.

Stola, D. (2010). Kraj bez wyjścia?: migracje z Polski 1949-1989 [A country with no exit?: International migrations from Poland, 1949-1989]. Instytut Pamięci Narodowej, Komisja Ścigania Zbrodni przeciwko Narodowi Polskiemu.

Titkow, A. (1993). Political change in Poland: Cause, modifier, or barrier to gender equality? In N. Funk, \& M. Mueller (Eds.), Gender politics and post-communism. Reflections from Eastern Europe and the former Soviet Union. New York: Routledge.

Titkow, A., Duch-Krzystoszek, D., \& Budrowska, B. (2004). Nieodpatna Praca Kobiet: Mity, Realia, Perspektywy [Women's unpaid work: myths, reality, perspectives]. Warszawa Wydawn: Institutu Filozofii i Socjologii PAN.

Urbańska, S. (2008). Transnarodowość jako perspektywa ujęcia macierzyństwa w warunkach migracji [Transnational perspective on motherhood in migration process]. In K. Slany (Ed.), Migracje kobiet. Perspektywa wielowymiarowa [Women's migration. An multidimensional perspective]. Kraków: Wydawnictwo Uniwersytetu Jagiellońskiego.

Urbańska, S. (2015). Matka Polka na odleglość. Z doświadczeń migracyjnych robotnic 1989-2010 [Polish Mothering at a distance. From the experiences of female migrant laborers in the 1989-2010 period]. Wydawnictwo Naukowe UMK.

Watson, P. (1993). The rise of masculinism in Eastern Europe. New Left Review, 198, 71-82.

White, A. (2011). Polish families and migration since EU accession. Policy Press.

Wojnicka, K., \& Ciaputa, E. (Eds.) (2011). Karuzela z mężczyznami. Problematyka męskości w polskich badaniach społecznych [Carousel with men. Masculinities' issues in Polish social research]. Kraków: Oficyna Wydawnicza Impuls.

\section{Submit your manuscript to a SpringerOpen ${ }^{\circ}$ journal and benefit from:}

- Convenient online submission

- Rigorous peer review

- Open access: articles freely available online

- High visibility within the field

- Retaining the copyright to your article

Submit your next manuscript at $\boldsymbol{\nabla}$ springeropen.com 